\title{
Study on the opening of a new working place in Romania of an European expedition house
}

\author{
Liliana Georgeta Popescu ${ }^{1 *}$, and Mihaela Elena Frăţilă ${ }^{2}$ \\ ${ }^{1}$ Lucian Blaga University of Sibiu, Industrial Engineering and Management Department, 550025, \\ Victoriei, no.10, Sibiu, Romania \\ ${ }^{2}$ S.C. Englmayer Romania S.R.L., Sibiu, Romania
}

\begin{abstract}
The present paper aims to carry out the case study on the possibility of opening a new working point of Englmayer Spedition GMBH in Dolj County. Starting from the current situation of Sibiu's work point and based on the results of the measurements, the necessity of opening a new working point is demonstrated. Englmayer is a transport and delivery company headquartered in Austria, with many work points in Europe including 5 terminals in Romania. The case study includes the presentation of the current situation on the Sibiu work point, followed by the calculations required to highlight the need to open a new work point in Dolj county. This new working point will take over part of the daily work from Sibiu's workstation. An analysis of the risk of opening the new workspace and the improvements was made in order to minimize the risks. It was used the FMEA procedure. Business improvement proposals includes the solutions found to make the workplace useful and to bring profit to the community.
\end{abstract}

\section{Introduction}

As early as 1991, the US National Physical Distribution Board, which in the meantime became the National Logistics Management Board, recognizing the importance of this logistics concept, defined it as "a process of planning, making and controlling flow and storage efficient and effective raw materials, processed products, finished products and related information, from the point of origin to the consumer, in order to adapt to customer requirements." [1] In current practice through logistics is meant the use in the technicaleconomic activity of modern means of calculation for finding the best solutions to solve the problems that arise in the processes of production and transport.

The objectives pursued by the expeditions house are as follows:

- ensuring the planned service level at the lowest cost.

- reducing space and time distances between supply and demand of goods, that is, between the two extremes of the distribution channel.

- reducing storage and distribution costs.

* Corresponding author: liliana.popescu@ulbsibiu.ro 
Organizing the transports is done by determining the volume of freight, the transport distances on the routes on which the transport is to be carried out. Once they have been established, the starting points, intermediate points and final points will be established.

\section{Case Study}

Englmayer Romania is an independent Austrian expeditionary house offering complete logistics services, especially in Central Europe being a partner with more than 150 years of experience. It manages 15 work points in Europe - 4 work points in Austria, 2 work points the Czech Republic, 1 workspace in Slovakia, Hungary, Slovenia, Croatia and 5 working points in Romania.[2]

At present, Sibiu Teminal provides the supply for 10 counties in Romania (Harghita, Covasna, Brasov, Sibiu, Alba, Hunedoara, Valcea, Gorj, Mehedinti, Dolj).

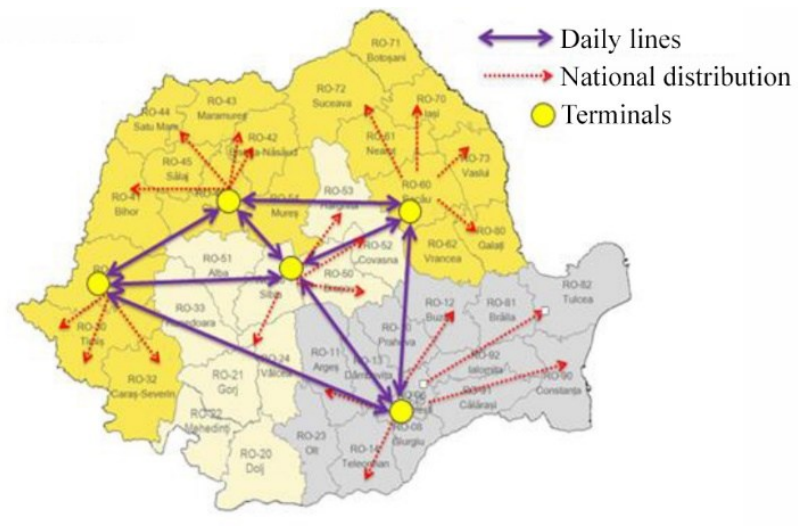

Fig. 1. Location of Englmayer Terminals in Romania

Using real data, the authors, were are analysed all the routes made by the 25 trucks (with 24-tonne capacity) that operate in the Sibiu terminal, in order to see how they are distributed, to calculate the number of kilometres, routes and costs during one year.

\begin{tabular}{|c|c|c|c|c|c|c|c|c|c|c|c|c|c|c|c|}
\hline \multirow[t]{2}{*}{ P2822 } & \multirow{2}{*}{\multicolumn{2}{|c|}{ A }} & \multirow{2}{*}{$\begin{array}{ll}\times & \times \\
& \\
B\end{array}$} & \multirow{2}{*}{$\begin{array}{l}f_{x} \\
c\end{array}$} & \multicolumn{11}{|c|}{ 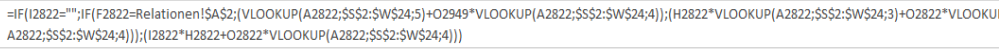 } \\
\hline & & & & & E & G & $\mathrm{H}$ & I & J & $\mathrm{k}$ & L & M & $\mathrm{N}$ & 0 & $\mathrm{p}$ \\
\hline 1 & Auto & 4 & Month $=$ & Wee- -1 & loading date 7 & Local/kM- & KM $\nabla$ & Tariff/KM & Delive $=$ & Weight $D$ & collecting $\mathrm{T}$ & Weight: $=$ & Total stor: $=$ & additional stc $=$ & Total cost \\
\hline 2822 & SB 49 LOW & & 11 & 49 & 29.11.2016 Rm Valcea-Targu Jiu & KM & 470 & & 6 & 1.887 & & & 6 & 4 (1) & 624,00 \\
\hline $2823 \mathrm{SE}$ & SB 49 LOW & & 9 & 38 & 13.09.2016 Rm Valcea-Tarģu Jiu-Dts & KM & 660 & & 7 & 1.285 & & & 7 & 5 & 867,00 \\
\hline $2824 \mathrm{SE}$ & SB 49 LOW & & 9 & 40 & 27.09.2016 Rm Valcea-Targu Jiuiu & $\mathrm{kM}$ & 470 & & 5 & 2.048 & & & 5 & 3 & 609,00 \\
\hline $2825 \mathrm{se}$ & SB 49 LDW & & 7 & 28 & 06.07.2016 RmV & KM & 230 & & 2 & 1.850 & & & 2 & & 276,00 \\
\hline $2826 \mathrm{sE}$ & SB 49 LOW & & 7 & 28 & 08.07.2016 RmV+Medias & $\mathrm{kM}$ & 370 & & 3 & 261 & 1 & 1.500 & 4 & 2 & 474,00 \\
\hline $2827 \mathrm{se}$ & SB 49 LOW & & 10 & 42 & 13.10.2016 RmV+Medias & $\mathrm{kM}$ & 400 & & 4 & 1.700 & & & 4 & 2 & 510,00 \\
\hline $2828 \mathrm{se}$ & SB 49 LOW & & 10 & 41 & 04.10.2016 Slatina-Craiova & $\mathrm{kM}$ & 504 & & 4 & 1.100 & & & 4 & 2 & 634,80 \\
\hline $2829 \mathrm{~s}$ & SB 49 LOW & & 11 & 45 & 02.11.2016 Sl-Calafat & $\mathrm{kM}$ & 687 & 1,35 & 6 & 2.378 & & & 6 & 4 & 987,45 \\
\hline $2830 \mathrm{sE}$ & SB 49 LOW & & 10 & 43 & 21.10.2016 \$l-CorăsțieAlba Iuliaa & KM & 564 & & 4 & 1.509 & & & 4 & 2 & 706,80 \\
\hline $2831 \mathrm{se}$ & SB 49 LOW & & 12 & 53 & 27.12.2016 sl-Craiova & $\mathrm{kM}$ & 544 & & 3 & 1.729 & 1 & 200 & 4 & 2 & 682,80 \\
\hline $2832 \mathrm{sE}$ & SB 49 LOW & & 5 & 21 & 20.05.2016 sl-Ostroveni & KM & 632 & & 3 & 1.845 & & & 3 & 1 & 773,40 \\
\hline $2833 \mathrm{se}$ & SB 49 LOW & & 6 & 25 & 13.06.2016 Targu Jiu & $\mathrm{kM}$ & 523 & & 5 & 2.105 & & & 5 & 3 & 672,60 \\
\hline $2834 \mathrm{sE}$ & SB 49 LoW & & 6 & 25 & 14.06.2016 Targu Jiu & KM & 480 & & 5 & 1.058 & & & 5 & 3 & 621,00 \\
\hline $2835 \mathrm{st}$ & SB 49 LOW & & 7 & 29 & 12.07.2016 Targu Jiu & $\mathrm{kM}$ & 450 & & 5 & 1.763 & & & 5 & 3 & 585,00 \\
\hline $2836 \mathrm{se}$ & SB 49 LOW & & 8 & 34 & 19.08.2016 Targu Jiu & $\mathrm{kM}$ & 450 & & 4 & 985 & & & 4 & 2 & 570,00 \\
\hline $2837 \mathrm{sE}$ & SB 49 LOW & & 9 & 36 & 02.09.2016 Targu Jiu & $\mathrm{kM}$ & 490 & & 3 & 1.119 & & & 3 & 1 & 603,00 \\
\hline $2888 \mathrm{~s}$ & SB 49 LOW & & 9 & 38 & 14.09.2016 Targu Jiv & $\mathrm{KM}$ & 450 & & 3 & 1.726 & & & 3 & 1 & 555,00 \\
\hline $2839 \mathrm{sE}$ & SB 49 LOW & & 10 & 45 & 31.10.2016 Targu Jiu & $\mathrm{kM}$ & 450 & & 4 & 1.797 & & & 4 & 2 & 570,00 \\
\hline $2840 \mathrm{se}$ & SB 49 LOW & & 11 & 46 & 11.11.2016 Targu Jiu & $\mathrm{KM}$ & 450 & & 4 & 2.051 & & & 4 & 2 & 570,00 \\
\hline $2841 \mathrm{se}$ & SB 49 LOW & & 12 & 51 & 15.12.2016 Targu Jiu & $\mathrm{kM}$ & 550 & & 4 & 1.800 & 1 & 50 & 5 & 3 & 705,00 \\
\hline $2842 \mathrm{SE}$ & SB 49 LOW & & 12 & 52 & 19.12.2016 Targu Jiu & KM & 480 & & 6 & 2.249 & & & 6 & 4 & 636,00 \\
\hline $2843 \mathrm{se}$ & SB 49 LOW & & 11 & 46 & 08.11.2016 Targu Jiu-Bumbesti & $\mathrm{KM}$ & 490 & & 5 & 2.221 & 1 & 369 & 6 & 4 & 648,00 \\
\hline $2844 \mathrm{~T}$ & Total & & & & & & 1.515 .822 & 592,97 & 17.312 & $7.831 .400,57$ & 4.769 & 6.315.111 & 23.629 & 17.990 & $2.285 .291,71$ \\
\hline
\end{tabular}

Fig. 2. Centralize data related to all races completed in one year at the Sibiu Terminal 
Following the centralization of all the races performed by the 25 trucks it was found that they performed a total of $1,515,822 \mathrm{~km}$ for the 2842 races in the 10 counties in Romania, the cost of which was around 507,842 Euro.

There was an idea to of open a new terminal in Craiova, Dolj County (noted with RO 20 Dolj in Figure 1). All the races for the Gorj, Dolj, Mehedinţi, Valcea counties (marked in Figure 1 with RO 21 Gorj, RO 20 Dolj, RO 22 Mehedinti, RO 24 Vâlcea) were selected and recalculated with the starting point Craiova. In figure 2 there are presented the calculation for 3 month of kilometres done from Sibiu Terminal and the simulation of the number of kilometres from proposed Craiova Terminal. There is a decrease in the number of kilometres with 26,371 km for June, 20,550 km for July and 25,243 km for August.

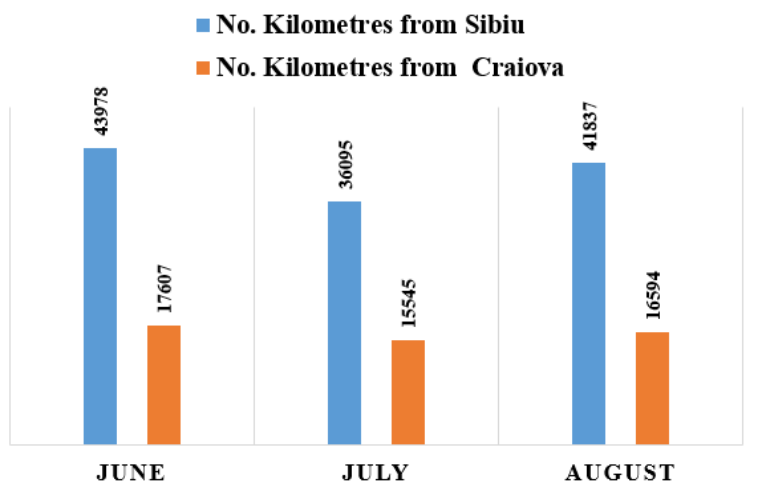

Fig. 2. Comparison between Sibiu and Craiova regarding the number of kilometres recorded in June, July and August

The resulting transport costs were compared with those made with the departure point of Sibiu. Differences / race were on average 100 euros less if the delivery was made from the Craiova terminal.

\section{Analysis of the opening of a new working point in Dolj County}

In order to open a new terminal, the working team proposed some initial expenditure for the opening the deposit. It was calculated if the difference of costs obtained as a profit cover or not the monthly costs with the opening of the new Craiova workstation. Beside this there is necessary to make a detailed analysis. For this analysis it was used AMDEC or FMEA method (Failure Mode Effects Analysis).

\subsection{Methodology description}

The proposed method for this analysis is found in the literature under the names of AMDEC (Analyse des Modes De Éfaillance de leurs effets et de leur Criticité, in French), or FMEA - FMECA (Failure Modes, Effects and Criticalitz Analysis, in English). AMDEC / FMEA is an analytical method used to systematically identify possible failures from the design, manufacture, or assembly process for a product or a service. [3]

FMEA is a systematic procedure for a system analysis used to identify the possible fault modes, the causes and effects of each malfunction against system operation. A different definition has been formulated by Goddard Space Flight Center (USA): FMEA is a procedure by which each credible defect module of each element, from the lower to the 
highest level, is analysed to determine the effects on the system and to classify each possible way of defect according to the severity of its effect.

In order to identify the elements of the FMEA model, a teamwork approach is required. The firm application has been carried out involving a cross-functional and multidisciplinary team. [4-5] The FMEA team should include specialists from every field. This technique is applied in the following forms:

- FMEA project, shall apply after the construction design documentation stage;

- FMEA process, applies after the stage of elaboration of the technological documentation of the process for the realization of the product;

- FMEA equipment, applies after defining the system of machinery and technological equipment on which the technological process is carried out.

We consider the FMEA criteria as follows:

- the severity of failure $(\mathrm{G})$, an indicator that estimates the severity of the failure of the user

- probability of failure $(\mathrm{F})$, which estimates the probability of failure;

- the probability of failure detection (D), an indicator that estimates the probability of timely detection of the nonconformity of execution (or process);

When FMEA is done by a team, the payback is realized by identifying potential failures and reducing failure cost because of the collective expertise of the team in understanding how the design/process works. FMEA is highly subjective and requires considerable guesswork on what may and could happen, and means to prevent this. If data is not available, the team may design an experiment, collect data, or simply pool their knowledge of the process.[6]

\subsection{FMEA on the opening of the new working point}

The FMEA criteria formulated for analysing the process of opening a warehouse in another city are the severity of the effect (Table 1), the occurrence frequency (Table 2), the Defects Discovery (Table 3)

Table 1. The severity of the effect

\begin{tabular}{|l|l|c|}
\hline \multicolumn{1}{|c|}{ Effect } & \multicolumn{1}{|c|}{ The severity of the effect } & G \\
\hline $\begin{array}{l}\text { Risky, without } \\
\text { prevention }\end{array}$ & The company may be on the verge of bankruptcy & 10 \\
\hline Risky, with prevention & The company may be on the verge of bankruptcy & 9 \\
\hline Very important & $\begin{array}{l}\text { The process can be resumed in the same department, lasting } \\
\text { more than an hour }\end{array}$ & 8 \\
\hline Important & $\begin{array}{l}\text { The process can be resumed in the same department within } \\
\text { half an hour or an hour }\end{array}$ & 7 \\
\hline Moderate & $\begin{array}{l}\text { The process can be resumed in the same department in less } \\
\text { than half an hour }\end{array}$ & 6 \\
\hline Reduced & $\begin{array}{l}\text { The process can be resumed without interference by } \\
\text { operators of another department }\end{array}$ & 5 \\
\hline Very low & $\begin{array}{l}\text { The calculations / measurements can be restored by the same } \\
\text { operator }\end{array}$ & 4 \\
\hline Minor & $\begin{array}{l}\text { You can remake the calculations / measurements by another } \\
\text { operator }\end{array}$ & 3 \\
\hline Very minor & $\begin{array}{l}\text { You can remake calculations / measurements right at the } \\
\text { main place }\end{array}$ & 2 \\
\hline Not at all & Very little problems in the process & 1 \\
\hline
\end{tabular}


Table 2. Frequency of occurrence

\begin{tabular}{|l|l|c|}
\hline Probability of failure & \multicolumn{1}{|c|}{ Frequency } & F \\
\hline \multirow{2}{*}{ Very big } & The failure is almost inevitable, unusable, and inappropriate. & 10 \\
\cline { 3 - 3 } Big & $\begin{array}{l}\text { Generally associated with processes similar to previous } \\
\text { processes that often have failed, unstable process. }\end{array}$ & 9 \\
\hline \multirow{2}{*}{ Moderate } & $\begin{array}{l}\text { Generally associated with processes similar to previous } \\
\text { processes that had occasional but not major failures, less } \\
\text { stable process. }\end{array}$ & 7 \\
\cline { 2 - 3 } Small & $\begin{array}{l}\text { Isolated defects associated with similar processes, stable } \\
\text { process. }\end{array}$ & 5 \\
\cline { 2 - 3 } & $\begin{array}{l}\text { The failure is unlikely. Never failures are associated with } \\
\text { identical processes. }\end{array}$ & 2 \\
\hline Removed & &
\end{tabular}

Table 3. Discovering the defect

\begin{tabular}{|l|l|c|}
\hline \multicolumn{1}{|c|}{ Discovery } & \multicolumn{1}{c|}{ Suggested detection methods } & D \\
\hline Almost impossible & Cannot be detected or verified. & 10 \\
\hline Very distant & The control is carried out by random or single random checks. & 9 \\
\hline Distant & Control is only done through visual inspections. & 8 \\
\hline Very small & The control is carried out by double visual inspections. & 7 \\
\hline Small & The control is done by tabular graphical methods & 6 \\
\hline Moderate & Control is based on standard variables & 5 \\
\hline Moderately large & $\begin{array}{l}\text { Errors detected in subsequent operations or by default standard } \\
\text { checks }\end{array}$ & 4 \\
\hline Big & $\begin{array}{l}\text { Detecting errors at the workstation / control or through more } \\
\text { acceptance checks performed on subsequent operations }\end{array}$ & 3 \\
\hline Very big & $\begin{array}{l}\text { Errors detected at the workstation / control by automated } \\
\text { standard checks with the possibility of stopping the process }\end{array}$ & 2 \\
\hline Very big & Using methods to prevent errors in the process & 1 \\
\hline
\end{tabular}

The steps to be followed in conducting an FMEA analysis are as follows:

- identifying functions, failure modes, and the effects of failure modes

- determining the severity and possible causes

- determining the frequency, detection and criticality index $(G * F * D)$

- taking corrective measures and reducing risks 
Table 4 FMEA analysis

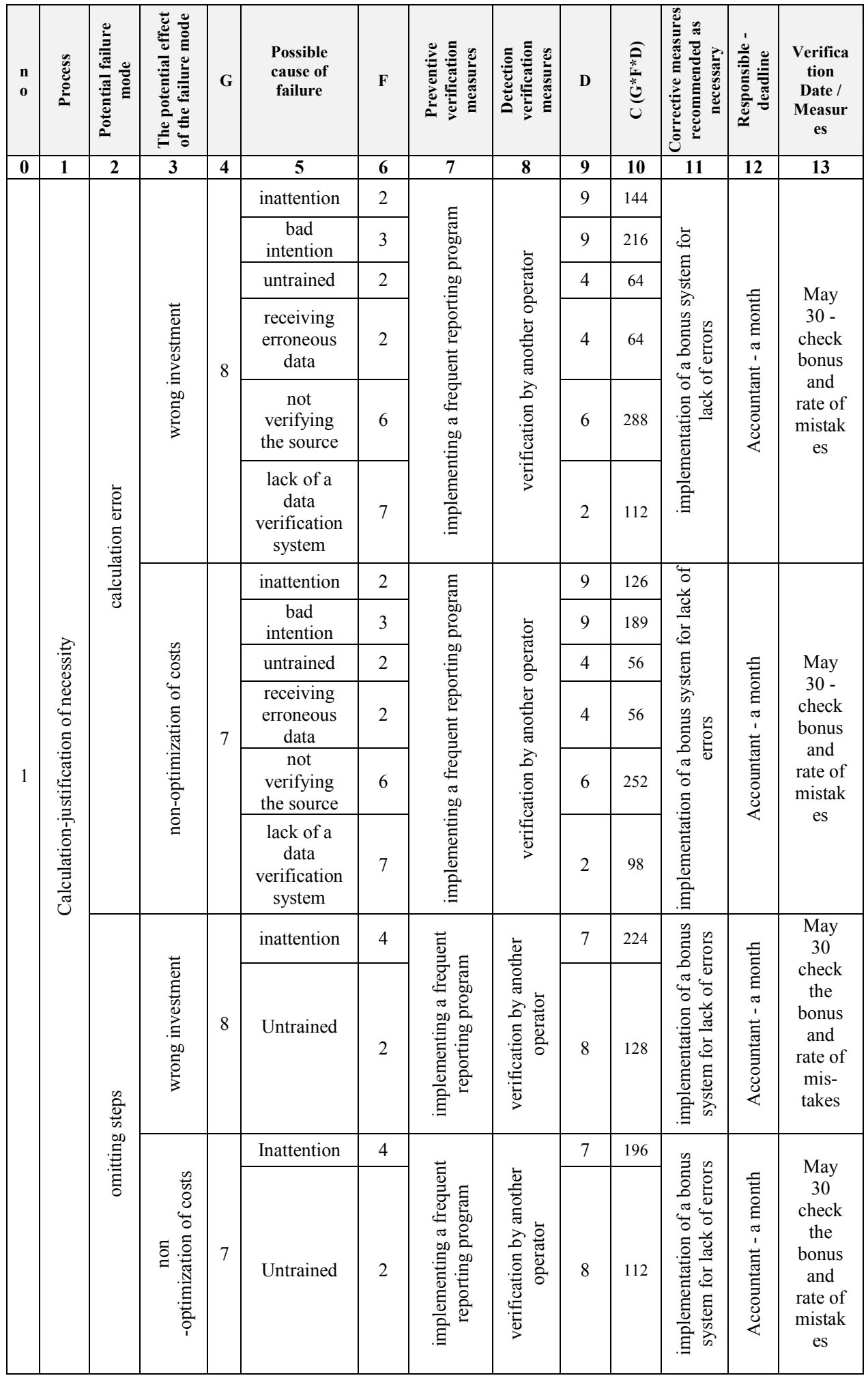




\begin{tabular}{|c|c|c|c|c|c|c|c|c|c|c|c|c|c|}
\hline & & & & & inattention & 6 & $\stackrel{00}{\Xi}$ & ẗ & 6 & 288 & छ & & \\
\hline & & & $\vec{\Xi}$ & & $\begin{array}{c}\text { bad } \\
\text { intention }\end{array}$ & 1 & $\begin{array}{l}0 \\
\stackrel{0}{0} \\
\stackrel{2}{0}\end{array}$ & $\begin{array}{l}\frac{\pi}{2} \\
0 \\
0 \\
:\end{array}$ & 7 & 56 & 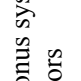 & 폼 & $\begin{array}{l}\text { May } \\
30\end{array}$ \\
\hline & & & $\stackrel{\Xi}{\Xi}_{\substack{0 \\
0}}$ & 8 & $\begin{array}{l}\text { receiving } \\
\text { erroneous } \\
\text { data }\end{array}$ & 4 & 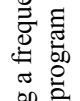 & $\begin{array}{l}\text { F } \\
\text { 总 } \\
\text { ટ }\end{array}$ & 6 & 192 & 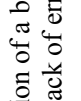 & 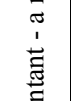 & $\begin{array}{l}\text { the } \\
\text { bonus } \\
\text { and }\end{array}$ \\
\hline & & 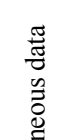 & 良 & & $\begin{array}{c}\text { not } \\
\text { verifying } \\
\text { the source }\end{array}$ & 4 & 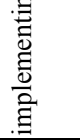 & .0.0 & 8 & 256 & 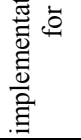 & : & $\begin{array}{l}\text { rate of } \\
\text { mistak } \\
\text { es }\end{array}$ \\
\hline & & $\begin{array}{l}5 \\
0 \\
00\end{array}$ & & & inattention & 6 & & & 6 & 252 & & & \\
\hline & & 䒕 & $\begin{array}{l}8 \\
4 \\
0 \\
=\end{array}$ & & $\begin{array}{c}\text { bad } \\
\text { intention }\end{array}$ & 1 & 芑 & 官泀 & 7 & 49 & 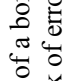 & $\underset{\Xi}{\stackrel{\Xi}{\Xi}}$ & $\begin{array}{c}30 \\
\text { check }\end{array}$ \\
\hline & & & . & 7 & $\begin{array}{l}\text { receiving } \\
\text { erroneous } \\
\text { data }\end{array}$ & 4 & 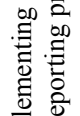 & 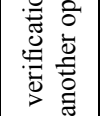 & 6 & 168 & 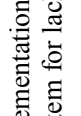 & 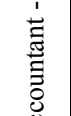 & $\begin{array}{l}\text { bonus } \\
\text { and } \\
\text { rate of }\end{array}$ \\
\hline & & & $\stackrel{\Xi}{0}$ & & $\begin{array}{c}\text { not } \\
\text { verifying } \\
\text { the source }\end{array}$ & 4 & .尹 & & 7 & 196 & 竝公 & \& & $\begin{array}{c}\text { mistak } \\
\text { es }\end{array}$ \\
\hline & & $\stackrel{\overrightarrow{0}}{\stackrel{ \pm}{a}}$ & & & $\begin{array}{l}\text { unverifying } \\
\text { conditions }\end{array}$ & 4 &.$\Xi$ & & 4 & 112 & ¿ัٌ & 氙 & \\
\hline & & 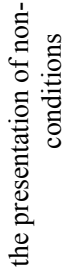 & 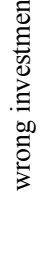 & 7 & $\begin{array}{l}\text { good faith } \\
\text { in the } \\
\text { owner }\end{array}$ & 6 & 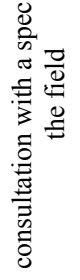 & 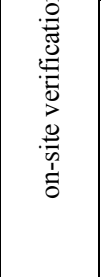 & 4 & 168 & 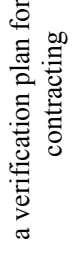 & 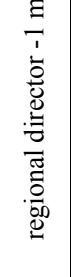 & $\begin{array}{l}\text { July } 3 \\
\text { verifica } \\
\text { tion } \\
\text { plan }\end{array}$ \\
\hline 2 & . & .ే & & & $\begin{array}{c}\text { receiving } \\
\text { erroneous } \\
\text { data }\end{array}$ & 4 & 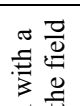 & 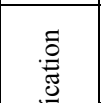 & 7 & 224 & 先 & & \\
\hline & $\ddot{z}$ & 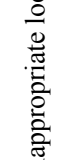 & 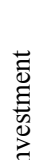 & & $\begin{array}{l}\text { ignorance / } \\
\text { omission of } \\
\text { legislative } \\
\text { conditions }\end{array}$ & 4 & 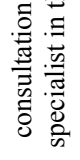 & $\begin{array}{l}.0 \\
0 \\
0 \\
0 \\
0 \\
0 \\
0 \\
0 \\
0\end{array}$ & 4 & 128 & 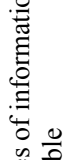 & 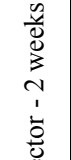 & July 17 \\
\hline & & 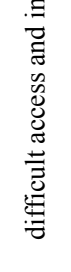 & 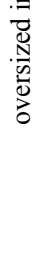 & 8 & $\begin{array}{l}\text { ignorance } \\
\text { of prices in } \\
\text { the area }\end{array}$ & 5 & 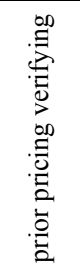 & 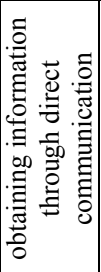 & 4 & 160 & 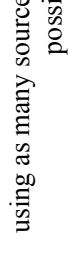 & 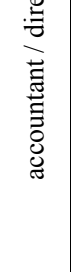 & $\begin{array}{l}\text { inform } \\
\text { ation }\end{array}$ \\
\hline & & & & & inattention & 3 & & $\dot{\bar{\Delta}}$ & 6 & 126 & 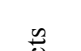 & & \\
\hline & 窇 & 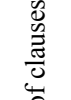 & $\begin{array}{l}\stackrel{\Xi}{\Xi} \\
\stackrel{\Xi}{\Xi} \\
. \Xi\end{array}$ & & $\begin{array}{c}\text { granting } \\
\text { undue trust }\end{array}$ & 2 & 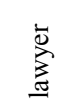 & 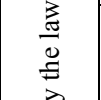 & 4 & 56 & 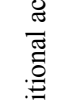 & 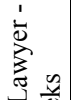 & $\begin{array}{l}\text { August } \\
\text { 2nd } \\
\text { verifica }\end{array}$ \\
\hline 3 & 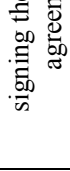 & 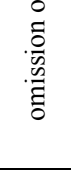 & $\begin{array}{l}\frac{0}{0} \\
\text { 兘 } \\
0 \\
\vdots \\
\vdots\end{array}$ & 7 & $\begin{array}{c}\text { not } \\
\text { understandi } \\
\text { ng the } \\
\text { possible } \\
\text { problems }\end{array}$ & 3 & $\begin{array}{l}\sigma \\
0 \\
0 \\
0\end{array}$ & 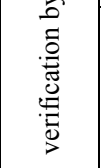 & 4 & 84 & 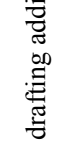 & 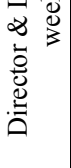 & $\begin{array}{l}\text { tion of } \\
\text { docum } \\
\text { ents }\end{array}$ \\
\hline
\end{tabular}




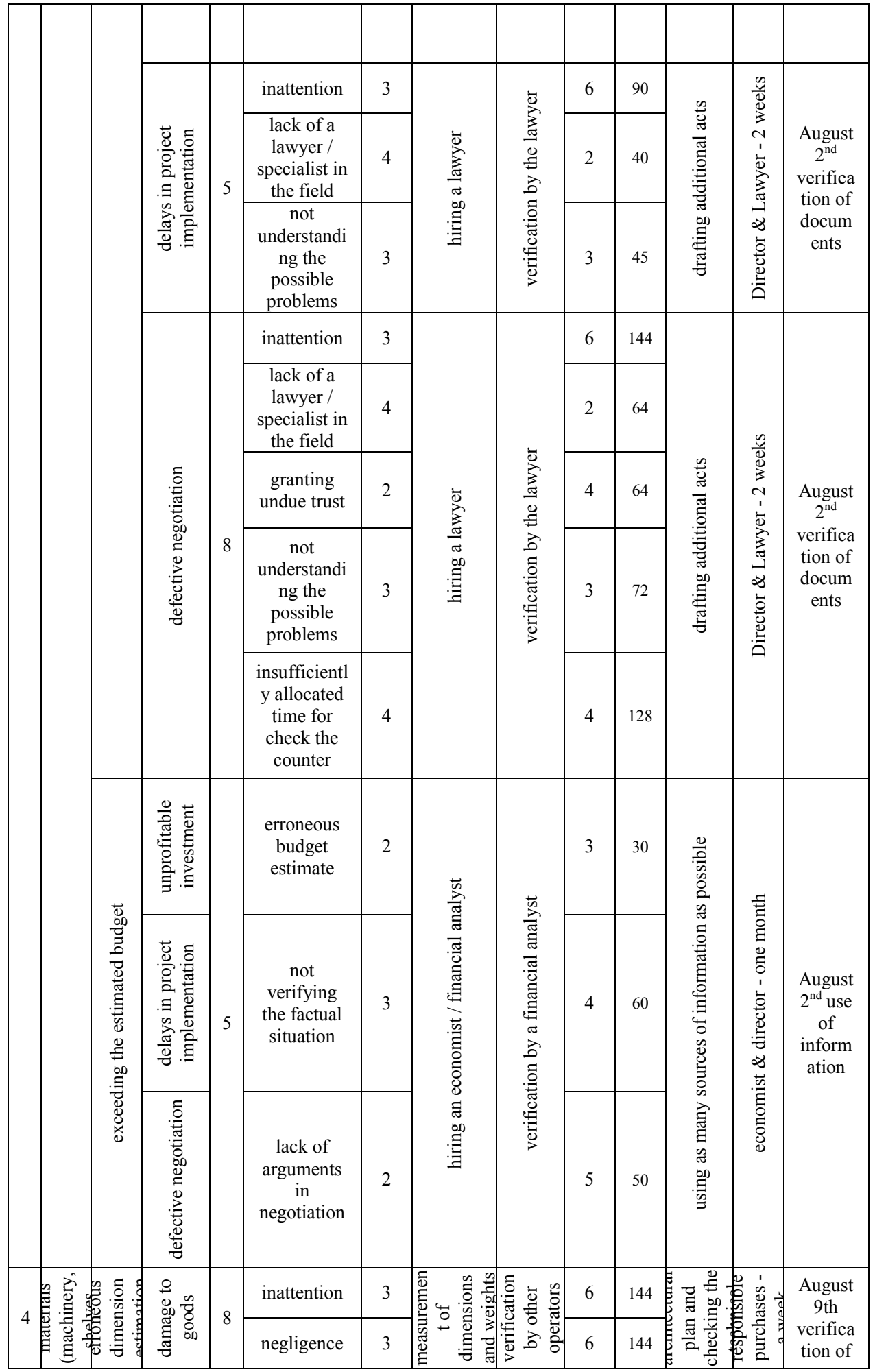




\begin{tabular}{|c|c|c|c|c|c|c|c|c|c|c|c|c|c|}
\hline & & & & & $\begin{array}{c}\text { uncorrelatio } \\
\mathrm{n} \text { of } \\
\text { acquisition } \\
\text { dimensions } \\
\text { with } \\
\text { location } \\
\text { area }\end{array}$ & 1 & & & 2 & 16 & & & $\begin{array}{l}\text { plan } \\
\text { and } \\
\text { fiches }\end{array}$ \\
\hline & & & 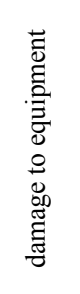 & 7 & $\begin{array}{l}\text { uncorrelatio } \\
\mathrm{n} \text { of } \\
\text { acquisition } \\
\text { dimensions } \\
\text { with } \\
\text { location } \\
\text { area and } \\
\text { specific } \\
\text { weight }\end{array}$ & 2 & 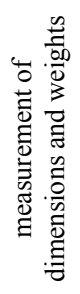 & 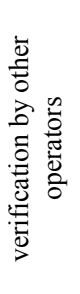 & 2 & 28 & & $\begin{array}{l}0 \\
1 \\
0 \\
0 \\
0 \\
0 \\
0 \\
0 \\
0 \\
0 \\
0 \\
0 \\
0 \\
0 \\
0 \\
0 \\
0 \\
0 \\
0 \\
0\end{array}$ & $\begin{array}{l}\text { August } \\
\text { 9th } \\
\text { verifica } \\
\text { tion of } \\
\text { plan } \\
\text { and } \\
\text { fiches }\end{array}$ \\
\hline & & & 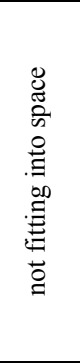 & 6 & $\begin{array}{c}\text { uncorrelatio } \\
n \text { of } \\
\text { acquisition } \\
\text { dimensions } \\
\text { with } \\
\text { location } \\
\text { area and } \\
\text { specific } \\
\text { weight }\end{array}$ & 2 & 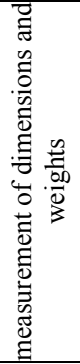 & 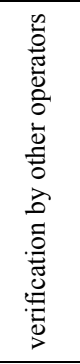 & 2 & 24 & & 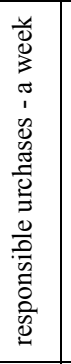 & $\begin{array}{l}\text { August } \\
\text { 9th } \\
\text { verifica } \\
\text { tion of } \\
\text { plan } \\
\text { and } \\
\text { fiches }\end{array}$ \\
\hline & & & & & inattention & 3 & $\tilde{0}$ & 总 & 6 & $\begin{array}{c}10 \\
8\end{array}$ & & $\frac{y}{\Xi}$ & \\
\hline & & & 莺 & & negligence & 3 & $\stackrel{\Xi}{\Xi}_{\infty}$ & ठั. & 6 & $\begin{array}{c}10 \\
8\end{array}$ & & $\begin{array}{l}0 \\
1 \\
1\end{array}$ & $\begin{array}{l}\text { August } \\
\text { 9th }\end{array}$ \\
\hline & & 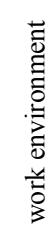 & 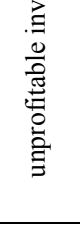 & 6 & $\begin{array}{l}\text { uncorrelatio } \\
\mathrm{n} \text { of } \\
\text { purchase } \\
\text { dimensions } \\
\text { with } \\
\text { location } \\
\text { area } \\
\end{array}$ & 2 & 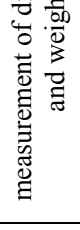 & 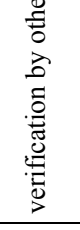 & 1 & 12 & & 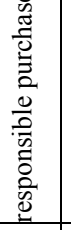 & $\begin{array}{l}\text { verifica } \\
\text { tion of } \\
\text { plan } \\
\text { and } \\
\text { fiches }\end{array}$ \\
\hline & & $\stackrel{\mathscr{E}}{ \pm}$ & 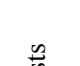 & & inattention & 3 & $\vec{\Xi}$ & $\tilde{a}$ & 6 & $\begin{array}{c}10 \\
8\end{array}$ & & $\frac{y}{8}$ & \\
\hline & & . & $\frac{0}{0}$ & & negligence & 3 & $\cdot \frac{0}{0.0}$ & 苞 & 6 & $\begin{array}{c}10 \\
8\end{array}$ & & $\begin{array}{l}5 \\
\pi \\
1 \\
i\end{array}$ & August \\
\hline & & $\begin{array}{l}\text { 윰 } \\
\text { : } \\
\text { : }\end{array}$ & 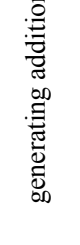 & 6 & $\begin{array}{c}\text { oncorrelatio } \\
\text { n of } \\
\text { purchase } \\
\text { dimensions } \\
\text { with } \\
\text { location } \\
\text { area }\end{array}$ & 2 & 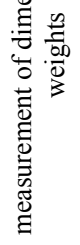 & 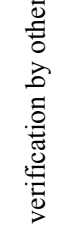 & 1 & 12 & & 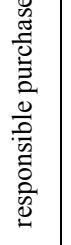 & $\begin{array}{l}\text { verifica } \\
\text { tion of } \\
\text { plan } \\
\text { and } \\
\text { fiches }\end{array}$ \\
\hline & $\stackrel{\infty 0}{\Xi}$ & & & & inattention & 3 & & $\begin{array}{l}\stackrel{\Xi}{\Xi} \\
\text { OD } \\
\Xi\end{array}$ & 6 & $\begin{array}{c}14 \\
4\end{array}$ & $\frac{\text { ㄹ }}{2}$ & 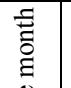 & \\
\hline & 青 & 蒈 & 兽: & & negligence & 3 & 馬 & 苞 & 6 & $\begin{array}{c}14 \\
4\end{array}$ & 蚵 & $\begin{array}{l}5 \\
\vdots \\
1\end{array}$ & $\begin{array}{l}\text { ber } \\
11 \text { th }\end{array}$ \\
\hline J & $\begin{array}{ll}0 & 0 \\
4 & 0 \\
0 & 0 \\
0 & 0 \\
0 & 0 \\
0 & 0 \\
0 & 0 \\
0 & 0 \\
0 & \end{array}$ & 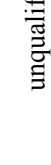 & 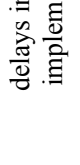 & 0 & untrained & 2 & 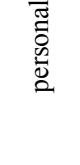 & 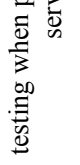 & 2 & 32 & $\begin{array}{l}0 \\
00 \\
.0 \\
\frac{0}{0} \\
\frac{0}{0} \\
\frac{0}{0}\end{array}$ & 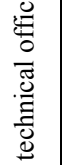 & $\begin{array}{c}\text { verifica } \\
\text { tion } \\
\text { plan }\end{array}$ \\
\hline
\end{tabular}




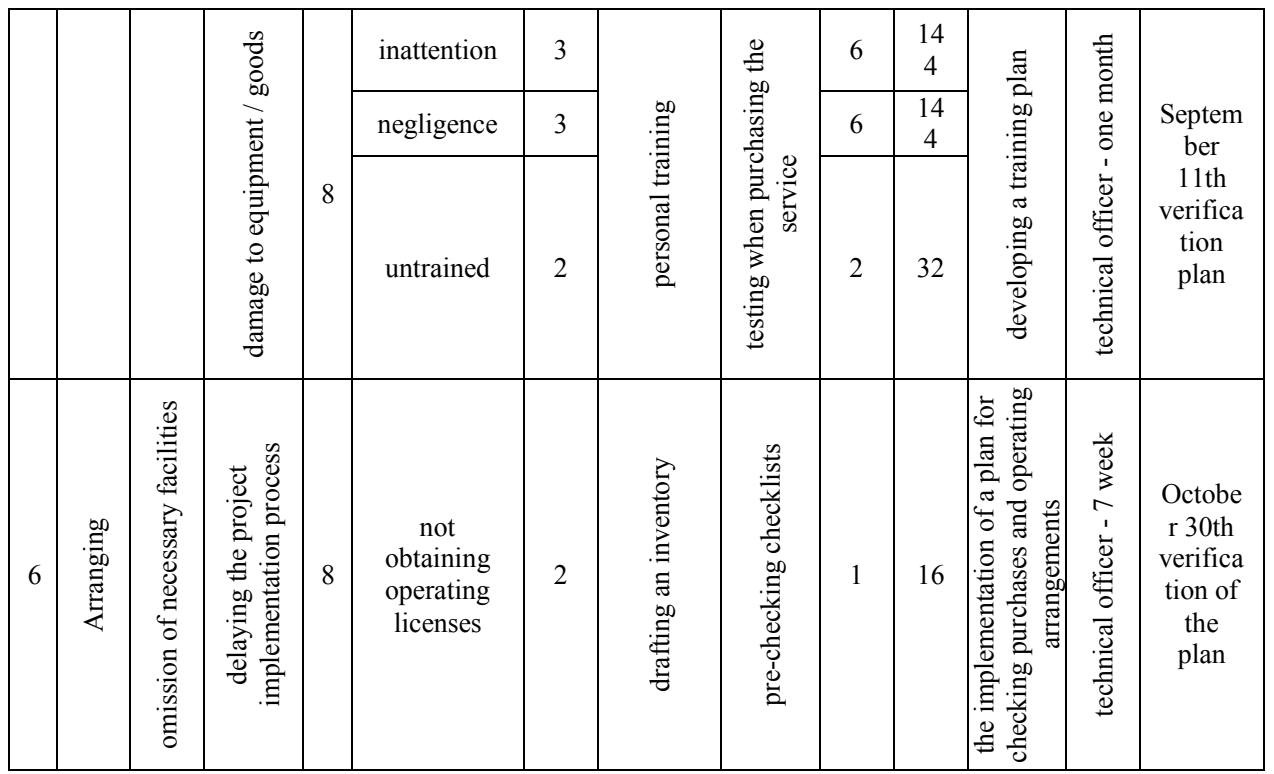

In conclusion, it is justified to open this new working point in Dolj - Craiova because the cost differences that will have to be provided by the company are very small and will be easy covered with profit in the near future. Due to the fact that centralized transport is organized, the rhythmic delivery conditions have a positive effect on the transport services of the company.

\section{Conclusions}

The study proposed in this paper aimed at analysing the working point in Sibiu of Englmayer, which operates freight services in Europe and throughout Romania. Calculations were made to determine the need to open a new workspace, to check the results and to compare current and future routes and cost comparisons. An analysis of the risk of opening the new workspace and the improvements was made in order to minimize the risks.

As a tool, Failure Mode and Effect Analysis is a one of the most effective low-risk techniques for predicting problems and identifying the most cost-effective solutions for preventing the problems. As a procedure, FMEA provides a structured approach for evaluating, tracking and updating design/process developments. It provides a format to link and maintain many company documents. As a diary, FMEA is started during design/process/service conception and continued throughout saleable life of the product. It is important to document and assess all changes that occur which affect quality or reliability.[6]

The analysis of the risks related to the opening of a new working point was made using the FMEA method. As a result of the calculations and the analysis it can be concluded that it is justified to open a new terminal in Craiova, Dolj County.

\section{References}

1. G. Caraiani, Logistica Transporturilor (Editura Universitara, Bucharest, 2008)

2. http://www.englmayer.ro/ 
3. L. Lobont, M.V. Zerbes, Metode, tehnici si intrumente pentru imbunatatirea calitatii, (Editura Universitatii Lucian Blaga din Sibiu, Sibiu, 2014)

4. L.G. Popescu, M.V. Zerbes, C. Kifor, Techniques and tools proposed to improve the quality of educational management in Engineering Faculty of the University "Lucian Blaga" Sibiu, Buletinul Universitatii Petrol-Gaze din Ploiesti, Romania (2010)

5. C. Paciarotti, G. Mazzuto, D. D'Ettorre, A revised FMEA application to the quality control management, International Journal of Quality \& Reliability Management, 31, 7, pp.788-810, https://doi.org/10.1108/IJQRM-02-2013-0028 (2014)

6. https://www.juran.com/blog/guide-to-failure-mode-and-effect-analysis-fmea/ 